\title{
Analiza zmian jakości powietrza Małopolski w latach 2012-2020
}

\section{Analysis of air quality changes in Małopolska in the years 2012-2020}

\author{
Mateusz Rataj, Jadwiga Holewa-Rataj \\ Instytut Nafty i Gazu - Państwowy Instytut Badawczy
}

\begin{abstract}
STRESZCZENIE: W artykule skupiono uwagę na problemie zanieczyszczenia powietrza, określanego mianem smogu, które według Światowej Organizacji Zdrowia (WHO) jest przyczyną śmierci 4,2 mln osób rocznie. W Europie problem smogu szczególnie dotyczy Polski - zgodnie z danymi WHO wśród 50 najbardziej zanieczyszczonych smogiem miast europejskich aż 33 znajdują się w Polsce. W trosce o zdrowie mieszkańców polskie prawo dało władzom samorządowym możliwość wprowadzania uchwał antysmogowych. Na tej podstawie uchwały takie podjęto w 11 województwach. Uchwały antysmogowe koncentrują się w głównej mierze na ograniczaniu emisji pyłów z sektora komunalno-bytowego. Według danych Krajowego Ośrodka Bilansowania i Zarządzania Emisjami sektor ten odpowiada za około 49\% emisji pyłów do atmosfery w Polsce. Również władze Małopolski w latach 2016 (dla miasta Krakowa) i 2017 (dla pozostałego obszaru) podjęły uchwały antysmogowe. Należy dodać, że działania w ramach realizacji programów ochrony powietrza w Małopolsce realizowano już znacznie wcześniej. W latach 2013-2018 na obszarze Małopolski zlikwidowano 43,6 tys. kotłów i pieców wykorzystujących paliwa stałe, w tym 22,5 tys. w samym Krakowie. W artykule przeanalizowano zmiany jakości powietrza na terenie Małopolski w latach 2012-2020. Podczas analizy danych skoncentrowano się na pięciu podstawowych zanieczyszczeniach wchodzących w skład smogu (tj. pyły PM10 oraz PM2,5, tlenki azotu, ditlenek siarki i tlenek węgla) oraz odczytach ośmiu stacji monitorowania jakości powietrza (trzy stacje zlokalizowane w Krakowie oraz pięć stacji poza Krakowem). Głównym celem analizy było wykazanie, czy podejmowane w Małopolsce działania prowadzą do poprawy jakości powietrza. W tym celu analizie poddano zarówno zmiany występujące $w$ średnich dobowych i średnich rocznych stężeniach zanieczyszczeń odnotowywanych przez poszczególne stacje pomiarowe, jak i zmiany w liczbie dni w sezonie grzewczym, w których odnotowywane były przekroczenia wartości dopuszczalnych. Analiza dostępnych danych pomiarowych za lata 2012-2020 wyraźnie pokazała, że występują zanieczyszczenia, dla których dopuszczalna zawartość w powietrzu jest wielokrotnie przekraczana w ciągu roku na terenie całego województwa. Przy czym w analizowanym okresie zauważalne są trendy spadkowe w odnotowywanych stężeniach poszczególnych zanieczyszczeń w powietrzu, co świadczy o tym, że podejmowane w województwie małopolskim działania w zakresie poprawy jakości powietrza przynoszą powoli efekty.
\end{abstract}

Słowa kluczowe: smog, ekoprojekt, jakość powietrza.

ABSTRACT: The article focuses on the problem of air pollution, which is referred to as smog, which, according to the WHO, causes the death of 4.2 million people annually. In Europe, the problem of smog particularly affects Poland, according to WHO data, among the 50 most polluted European cities, as many as 33 are in Poland. Out of concern for the health of the residents, Polish law has given local authorities the opportunity to introduce anti-smog resolutions. Anti-smog resolutions focus mainly on reducing dust emissions from the municipal and housing sector, and according to the data of the National Centre for Balancing and Emissions Management, it is responsible for approximately $49 \%$ of dust emissions into the atmosphere in Poland. Małopolska also adopted anti-smog resolutions in 2016 (for the city of Kraków) and 2017 (for the remaining area of the voivodeship). Nevertheless, actions under the implementation of air protection programs in Małopolska have been undertaken much earlier. In the years 2013-2018, 43.6 thousand boilers and stoves using solid fuels were decommissioned in Małopolska, including 22.5 thousand in Kraków alone. The article analyzes the changes in air quality in Małopolska in the years 2012-2020. The data analysis focused on five basic pollutants included in smog (i.e. PM10 and PM2.5 dust, nitrogen oxides, sulfur dioxide and carbon monoxide) and the readings of 8 air quality monitoring stations ( 3 located in the city of Krakow and 5 stations located outside Krakow). The main purpose of the analysis was to show whether the measures taken in Małopolska lead to the improvement of air quality. For this purpose, both changes in daily average and annual average pollutant concentrations recorded by individual measurement stations, as well as changes in the number of days in the heating season in which the limit values were exceeded were analyzed. The analysis of the available measurement data for the years 2012-2020 clearly showed that there are pollutants for which the permissible content in the air is exceeded many times a year throughout the voivodeship. At the same time, in the analyzed period, there are noticeable decreasing trends in the observed concentrations of individual pollutants in the air, which proves that the measures taken in Małopolska to improve air quality are slowly bringing results.

Key words: smog, ecodesign, air quality.

Autor do korespondencji: M. Rataj, e-mail: mateusz.rataj@inig.pl

Artykuł nadesłano do Redakcji: 06.08.2020 r. Zatwierdzono do druku: 04.11.2020 r. 


\section{Wstęp}

W trzeciej dekadzie XXI wieku coraz bardziej istotne stają się problemy związane z ochroną środowiska, w szczególności dotyczące przeciwdziałania zmianom klimatu oraz wspierające działania na rzecz poprawy jakości powietrza i minimalizacji zjawiska smogu. Mimo że oba te zjawiska (ocieplanie klimatu i występowanie smogu) mają różne podłoże fizykochemiczne i związane są z emisją różnych zanieczyszczeń do atmosfery, należy zauważyć, że przeciwdziałanie im w pewnych obszarach koncentruje się na podobnych aspektach, takich jak ograniczenie zużycia paliw kopalnych, zwiększenie udziału energii ze źródeł odnawialnych w bilansie energetycznym oraz zmniejszenie emisji zanieczyszczeń związanych z transportem i wytwarzaniem energii elektrycznej. Instytut Nafty i Gazu - Państwowy Instytut Badawczy od wielu lat zajmuje się zagadnieniami dotyczącymi ochrony środowiska $\mathrm{w}$ aspekcie przeciwdziałania zmianom klimatu oraz powstawaniu zjawiska smogu. W tym zakresie INiG - PIB prowadzi działania mające na celu upowszechnianie biopaliw (Rogowska, 2014, 2015, 2017, 2018; Rogowska et al., 2016), w tym biogazu (Holewa et al., 2012; Kołodziejak, 2012; Siuda i Wojtowicz, 2016), a od kilku lat również badania nad możliwością i bezpieczeństwem wykorzystania paliwa nieemisyjnego, jakim jest wodór, zarówno w czystej postaci, jak i mieszaniny z gazem ziemnym (Jaworski et al., 2019, 2020; Schuster et al., 2019; Wojtowicz, 2019). Dodatkowo INiG - PIB prowadzi badania urządzeń spalających paliwa gazowe oraz stałe, podczas których dokonywana jest między innymi analiza jakości spalin. Można więc stwierdzić, że działania INiG - PIB wpisują się zarówno w priorytety projektu polityki energetycznej Polski do 2040 roku w zakresie zwiększania udziału energii ze źródeł odnawialnych w zużyciu energii finalnej brutto, jak i w strategię ochrony jakości powietrza.

\section{Zjawisko smogu}

Termin „smog” został utworzony i upowszechnił się już na początku XX wieku w Wielkiej Brytanii. Obecnie w literaturze zjawisko smogu klasyfikowane jest na dwa rodzaje. Pierwszym z nich jest tzw. smog kwaśny, czyli londyński. Smog ten charakteryzuje się dużą zawartością tlenków siarki oraz pyłów w powietrzu. Jest on spowodowany głównie spalaniem paliw stałych. Drugi rodzaj smogu to smog fotochemiczny, zwany także smogiem Los Angeles. Jest on charakterystyczny dla obszarów miejskich, w których występuje duże natężenie ruchu samochodowego. Składnikami smogu fotochemicznego są głównie tlenki azotu oraz lotne związki organiczne (LZO) (Kamiński, 2019). Problem smogu w szczególny sposób dotyczy naszego kraju, gdyż według Światowej Organizacji Zdrowia wśród 50 najbardziej zanieczyszczonych smogiem miast europejskich aż 33 znajdują się w Polsce (Kuchcik i Milewski, 2018). Występujący w Polsce smog jest zazwyczaj smogiem fotochemicznym, ale nie zawsze można go jednoznacznie zdefiniować, ponieważ w powietrzu atmosferycznym w wyniku przemian chemicznych pojawiają się również inne substancje, nietypowe dla tego rodzaju smogu (Kamiński, 2019). Do szkodliwych składników gazowych zawartych w smogu można zaliczyć tlenki azotu, ditlenek siarki oraz tlenek węgla, które powodują podrażnienie górnych dróg oddechowych, zwiększają podatność na infekcje oraz zaostrzają objawy astmatyczne (PKEE, 2018). Równie niebezpieczne jak zanieczyszczenia gazowe są pyły występujące w smogu. Szacuje się, że na terenie Polski na ponadnormatywne stężenie pyłów w powietrzu narażonych jest ponad $15 \mathrm{mln}$ osób. Dodatkowo ocenia się, że zanieczyszczenie powietrza wywołane pyłami prowadzi rocznie do 4 milionów zgonów na świecie, a w Polsce do około 48 tys. zgonów (Głuszek i Kosicka, 2019).

\section{Działania na rzecz ograniczenia występowania smogu - uchwały antysmogowe}

W trosce o zdrowie mieszkańców polskie prawo dało władzom samorządowym możliwość wprowadzania uchwał antysmogowych. Stało się to na mocy Ustawy z dnia 27 kwietnia 2001 r. - Prawo ochrony środowiska (Dz.U. z 2015 r. poz. 1593), po jej nowelizacji, która nastąpiła w 2015 roku. Zgodnie z art. 96 tej ustawy sejmik województwa w drodze uchwały może wprowadzić ograniczenia lub zakazy w zakresie eksploatacji instalacji, w których następuje spalanie paliw. Jednak zgodnie z ustawą (Dz.U. z 2015 r. poz. 1593) uchwały nie mają zastosowania do instalacji, dla których wymagane jest uzyskanie pozwolenia zintegrowanego albo pozwolenia na wprowadzanie gazów lub pyłów do powietrza bądź dokonanie zgłoszenia, czyli nie dotyczą energetyki zawodowej. W powoływanej przez sejmik uchwale antysmogowej muszą być określone nie tylko granice obszaru, na którym zostaną wprowadzone nakazy i zakazy, ale również rodzaje podmiotów i instalacji, których ona dotyczy, a także parametry lub rozwiązania techniczne albo parametry emisji, w których następuje spalanie paliw dopuszczonych do stosowania na danym obszarze (Stala-Szlugaj, 2018). Na mocy ustawy (Dz.U. z 2015 r. poz. 1593) w 11 województwach podjęto uchwały antysmogowe; są to województwa: śląskie, małopolskie, wielkopolskie, mazowieckie, dolnośląskie, lubuskie, podkarpackie, opolskie, zachodniopomorskie, warmińsko-mazurskie oraz kujawsko-pomorskie (stan na wrzesień 2019 r.) (Life-Mappingair/PL, 2019). Zakres podjętych uchwał w poszczególnych województwach jest różny, ale koncentrują się one głównie na określeniu wymogów stawianym urządzeniom na 
paliwa stałe oraz ograniczeniom jakości paliw, jakie mogą być stosowane, lub całkowitej eliminacji paliw stałych wykorzystywanych w procesie ogrzewania. W zakresie wymogów dotyczących kotłów na paliwa stałe uchwały antysmogowe koncentrują się na rozwiązaniach zawartych w Rozporządzeniu Komisji (UE) 2015/1189 z dnia 28 kwietnia 2015 r. w sprawie wykonania dyrektywy Parlamentu Europejskiego i Rady 2009/125/WE w odniesieniu do wymogów dotyczących ekoprojektu dla kotłów na paliwo stałe (zwanej dalej ekoprojektem) (Rozporządzenie 2015/1189) lub w wymaganiach określonych w normie PN-EN 303-5:2012 stawianych kotłom klasy 5. Różnice w wymaganiach zawartych w przedmiotowym zakresie w obu tych dokumentach zebrano w tabeli 1.

Natomiast w zakresie ograniczeń w jakości stosowanych paliw stałych najczęściej spotykanymi rozwiązaniami są (Polski Alarm Smogowy, 2019):

- wykluczenie z użytkowania mułów, flotów i mieszanek z ich udziałem;

- zakaz stosowania węgla kamiennego o uziarnieniu mniejszym od $5 \mathrm{~mm}$ i zawartości popiołu większej niż 12\% lub

- zakaz stosowania węgla kamiennego w postaci sypkiej o uziarnieniu 0-3 mm, lub

- ograniczenie udziału węgla kamiennego o ziarnie 0-3 mm do $15 \%$ masowych, lub

- ograniczenie udziału węgla kamiennego o ziarnie 0-3 mm do $15 \%$ masowych, chyba że wartość opałowa węgla wynosi min. $24 \mathrm{MJ} / \mathrm{kg}$ i zawartość popiołu jest mniejsza od 12\%;

- ograniczenie stosowania biomasy o wilgotności w stanie roboczym powyżej $20 \%$.

Z danych przedstawionych powyżej wynika, że uchwały antysmogowe koncentrują się w głównej mierze na ograniczeniu emisji pyłów z sektora komunalno-bytowego, który według danych Krajowego Ośrodka Bilansowania i Zarządzania
Emisjami odpowiada za około 49\% emisji pyłów do atmosfery w Polsce (Treder, 2017).

\section{Działania na rzecz ograniczenia występowania smogu w Małopolsce}

W województwie małopolskim od wielu lat prowadzone są działania na rzecz ochrony powietrza. W ramach realizacji programów ochrony powietrza w latach 2013-2018 na obszarze Małopolski zlikwidowano 43,6 tys. kotłów i pieców wykorzystujących paliwa stałe, w tym 22,5 tys. w samym Krakowie (rys. 1). Dodatkowymi działaniami w tym zakresie było również

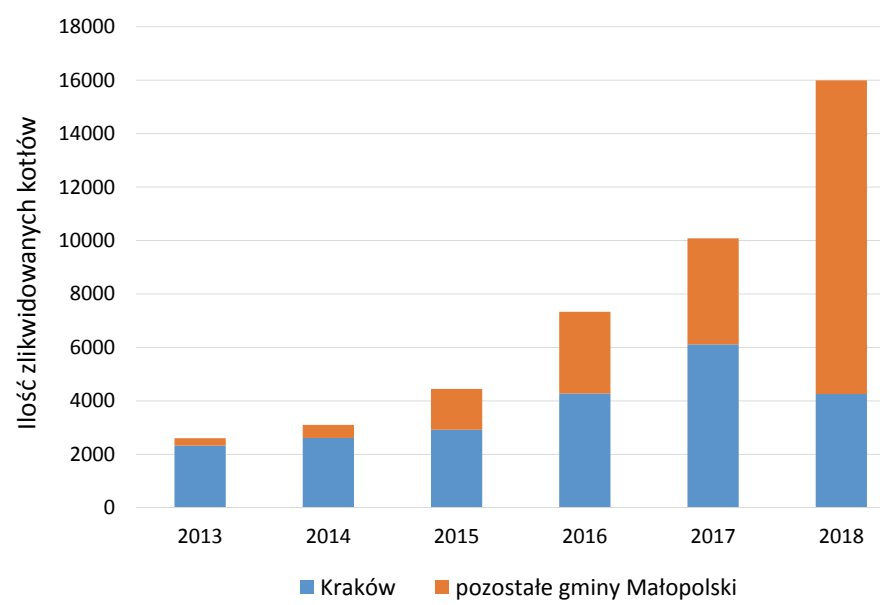

Rys. 1. Likwidacja kotłów na paliwa stałe na terenie Małopolski w latach 2013-2018 (Podsumowanie realizacji Programu ochrony powietrza dla województwa małopolskiego, 2013, 2014, 2015, 2016, 2017, 2018)

Fig. 1. Decommissioning of solid fuel boilers in Małopolska in 2013-2018 (Podsumowanie realizacji Programu ochrony powietrza dla województwa małopolskiego, 2013, 2014, 2015, 2016, 2017, 2018)

Tabela 1. Porównanie wymagań dla kotłów klasy 5 i wymagań ekoprojektu

Table 1. Comparison between the requirements for class 5 boilers and the ecodesign requirements

\begin{tabular}{|c|c|c|}
\hline $\begin{array}{l}\text { Wymagania dla kotłów na paliwa stałe } \\
\mathrm{z} \text { automatycznym podawaniem paliwa }\end{array}$ & $\begin{array}{c}\text { Kotly kl. } 5 \\
\text { (PN-EN 303-5:2012) }\end{array}$ & $\begin{array}{c}\text { Ekoprojekt } \\
\text { (Rozporządzenie 2015/1189) }\end{array}$ \\
\hline Efektywność energetyczna & $\begin{array}{l}\text { Sprawność kotła: od } 87 \% \text { do } 89 \% \text { (usta- } \\
\text { lana wg wzoru } \eta=87+\log \mathrm{Q} \text {, gdzie } \mathrm{Q} \\
\text { to moc cieplna kotła } \mathrm{wW} \text { ) }\end{array}$ & $\begin{array}{l}\text { Sezonowa efektywność energetyczna kotła: } \\
-75 \% \text { dla kotłów o znamionowej mocy ciepl- } \\
\text { nej do } 20 \mathrm{~kW} \text {; } \\
\text { - } 77 \% \text { dla kotłów o znamionowej mocy ciepl- } \\
\text { nej powyżej } 20 \mathrm{~kW}\end{array}$ \\
\hline Emisja tlenku węgla (CO) & $500 \mathrm{mg} / \mathrm{m}^{3}$ & $500 \mathrm{mg} / \mathrm{m}^{3}$ \\
\hline Emisja organicznych związków gazowych (OGC) & $20 \mathrm{mg} / \mathrm{m}^{3}$ & $20 \mathrm{mg} / \mathrm{m}^{3}$ \\
\hline Emisja pyłu (PM) & $40 \mathrm{mg} / \mathrm{m}^{3}$ & $40 \mathrm{mg} / \mathrm{m}^{3}$ \\
\hline $\begin{array}{l}\text { Emisja tlenków azotu }\left(\mathrm{NO}_{\mathrm{x}}\right) \text { wyrażonych jako } \\
\text { ekwiwalent dwutlenku azotu }\left(\mathrm{NO}_{2}\right)\end{array}$ & nie dotyczy & $\begin{array}{l}\text { - } 200 \mathrm{mg} / \mathrm{m}^{3} \text { dla kotłów na biomasę; } \\
-350 \mathrm{mg} / \mathrm{m}^{3} \text { dla kotłów na paliwa kopalne }\end{array}$ \\
\hline $\begin{array}{l}\text { Sposób weryfikacji wymagań w zakresie efektyw- } \\
\text { ności i emisji }\end{array}$ & $\begin{array}{l}\text { Wymagania muszą być spełnione dla pra- } \\
\text { cy kotła przy nominalnej mocy cieplnej, } \\
\text { a w przypadku emisji CO i OGC także } \\
\text { przy } 30 \% \text { nominalnej mocy cieplnej }\end{array}$ & $\begin{array}{l}\text { Wymagania muszą być spełnione dla średniej } \\
\text { ważonej wartości uzyskanych dla znamiono- } \\
\text { wej mocy cieplnej (z wagą } 0,15 \text { ) i przy } 30 \% \\
\text { znamionowej mocy cieplnej (z wagą } 0,85 \text { ) }\end{array}$ \\
\hline
\end{tabular}


przeprowadzenie termomodernizacji 5 tys. budynków oraz zainstalowanie odnawialnych źródeł energii w 12,9 tys. obiektów (Urząd Marszałkowski Województwa Małopolskiego, 2020a).

Dane przedstawione na rysunku 1 dowodzą, że działania na rzecz ochrony powietrza były podejmowane w Małopolsce o wiele wcześniej, niż weszły w życie uchwały antysmogowe obowiązujące w tym województwie. Obecnie w województwie małopolskim obowiązują dwie uchwały antysmogowe, tj. jedna uchwalona dla miasta Krakowa (Uchwała nr XVIII/243/16), druga dla pozostałej części Małopolski (Uchwała nr XXXII/452/17). Uchwała antysmogowa dla miasta Krakowa jest bardziej restrykcyjna niż dla reszty Małopolski. Na mocy uchwały nr XVIII/243/16 od 1 września 2019 roku na obszarze Krakowa w instalacjach spalania paliw, w szczególności kotłach, kominkach oraz piecach, jeżeli dostarczają ciepło do systemu centralnego ogrzewania lub wydzielają ciepło, dopuszczone jest stosowanie wyłącznie paliw gazowych lub lekkiego oleju opałowego. Uchwałą tą objęte są instalacje, które dostarczają ciepło do systemu centralnego ogrzewania (kotły) oraz instalacje wydzielające ciepło poprzez bezpośrednie przenoszenie ciepła lub w połączeniu z przenoszeniem ciepła do cieczy lub systemu dystrybucji gorącego powietrza (ogrzewacze pomieszczeń, piece, kominki i inne). Przepisy uchwały nr XVIII/243/16 dotyczą również wytwarzania ciepła na cele niegrzewcze i nie ograniczają się wyłącznie do budynków prywatnych. Obejmują więc także okazjonalne używanie kominków, ogrzewanie budynków gospodarczych, instytucji publicznych, szklarni i tuneli, suszarnie i obiekty gastronomiczne (Urząd Marszałkowski Województwa Małopolskiego, 2020b). Ponadto od 1 lipca 2017 roku w Małopolsce nie można eksploatować nowo zainstalowanego kotła na węgiel bądź drewno lub kominka o parametrach emisji gorszych niż wyznaczone w unijnych rozporządzeniach w sprawie ekoprojektu. Dodatkowo kocioł na paliwa stałe musi posiadać automatyczny podajnik paliwa i nie może być wyposażony w ruszt awaryjny (Urząd Marszałkowski Województwa Małopolskiego, 2020c). Wymiana zainstalowanych kotłów niespełniających wymagań ekoprojektu ma następować etapami (Urząd Marszałkowski Województwa Małopolskiego, 2020c):

- do końca 2022 roku konieczna jest wymiana kotłów na węgiel lub drewno, które nie spełniają żadnych norm emisyjnych;

- do końca 2026 roku należy wymienić kotły, które spełniają podstawowe wymagania emisyjne, czyli posiadają klasę 3 lub klasę 4 według normy PN-EN 303-5:2012;

- kotły spełniające wymagania klasy 5 według normy PN-EN 303-5:2012 mogą być użytkowane do końca swojej żywotności.

Uchwała małopolska (Uchwała nr XXXII/452/17) reguluje również kwestie jakości paliwa stałego. Od 1 lipca 2017 roku w całej Małopolsce obowiązuje zakaz stosowania mułów i flotów węglowych. Nie można również spalać węgla oznaczonego jako „miał”, gdyż zawartość frakcji poniżej $3 \mathrm{~mm}$ przekracza w nim 15\%. Obowiązuje także zakaz spalania drewna i biomasy o wilgotności powyżej 20\% (Urząd Marszałkowski Województwa Małopolskiego, 2020c). Działania wdrażane i zaplanowane na przyszłość w ramach uchwał antysmogowych w Małopolsce koncentrują się głównie na ograniczeniu emisji zanieczyszczeń w sezonie grzewczym wynikających z ogrzewania budynków.

\section{Zmiany jakości powietrza w Małopolsce na przestrzeni lat 2012-2020}

Wprowadzane przez władze województwa małopolskiego inicjatywy na rzecz poprawy jakości powietrza, a w ostatnim czasie także podjęte uchwały antysmogowe przyczyniły się do poprawy jakości powietrza w Małopolsce, szczególnie w sezonie grzewczym. W celu wskazania, jak poszczególne działania wpłynęły na jakość powietrza w Małopolsce przeanalizowano dane pochodzące z małopolskiego systemu jakości powietrza z lat 2012-2020 (WIOŚ, 2020). W przypadku zanieczyszczeń, dla których określone zostały średniodobowe dopuszczalne poziomy stężeń, analizowano dane wyłącznie dotyczące sezonu grzewczego od września do marca, natomiast w przypadku zanieczyszczeń, dla których określono wyłącznie średnioroczne wartości dopuszczalne, analizowano dane z całego roku. Podczas analizy skoncentrowano się na pięciu podstawowych zanieczyszczeniach, takich jak pyły PM10 oraz PM2,5, tlenki azotu, ditlenek siarki i tlenek węgla, oraz na danych pochodzących z wybranych ośmiu stacji monitorowania jakości powietrza: trzech zlokalizowanych w mieście Krakowie (stacje: al. Krasińskiego, Kurdwanów, Nowa Huta) oraz pięciu stacji zlokalizowanych poza Krakowem, w miejscowościach: Nowy Sącz, Skawina, Tarnów, Trzebinia, Zakopane.

Pierwszym z rozpatrywanych zanieczyszczeń są pyły zawieszone PM10, dla których określona została średniodobowa wartość dopuszczalna wynosząca $50 \mu \mathrm{g} / \mathrm{m}^{3}$. Wartość ta może być przekroczona maksymalnie 35 razy w ciągu roku (GIOŚ, 2020). Dane Wojewódzkiego Inspektoratu Ochrony Środowiska w Krakowie dotyczące jakości powietrza w zakresie zawartości pyłów PM10 na terenie Małopolski przedstawiono w tabeli 2.

$\mathrm{Z}$ danych przedstawionych w tabeli 2 wynika, że w większości analizowanych lokalizacji w poszczególnych sezonach grzewczych dochodziło do przekroczenia dopuszczalnej zawartości pyłów PM10 więcej niż 35 razy w ciągu roku (rys. 2). Wyjątek stanowiły wyniki zebrane dla lat 2015/2016 oraz 2019/2020 ze stacji Tarnów oraz 2018/2019 ze stacji Zakopane. Zauważyć można również, że najwięcej dni z przekroczeniem 
Tabela 2. Zawartość pyłów PM10 w powietrzu dla terenu Małopolski w latach 2012-2020 (WIOŚ, 2020)

Table 2. The content of PM10 dust in the air for the area of Małopolska in 2012-2020 (WIOŚ, 2020)

\begin{tabular}{|c|c|c|c|c|c|c|c|c|}
\hline $\begin{array}{c}\text { Sezon } \\
\text { grzewczy }\end{array}$ & $\begin{array}{c}\text { Kraków I } \\
\text { al. Krasińskiego }\end{array}$ & $\begin{array}{c}\text { Kraków II } \\
\text { Kurdwanów }\end{array}$ & $\begin{array}{l}\text { Kraków III } \\
\text { Nowa Huta }\end{array}$ & Nowy Sącz & Skawina & Tarnów & Trzebinia & Zakopane \\
\hline \multicolumn{9}{|c|}{ Liczba dni w sezonie grzewczym z przekroczeniem dopuszczalnej średniodobowej zawartości pyłu PM10 } \\
\hline $2012 / 2013$ & 135 & 118 & 96 & 114 & 118 & 59 & 56 & 78 \\
\hline $2013 / 2014$ & 137 & 95 & 103 & 90 & 88 & 37 & 57 & 76 \\
\hline $2014 / 2015$ & 162 & 95 & 107 & 93 & 87 & 38 & 58 & 67 \\
\hline $2015 / 2016$ & 145 & 89 & 93 & 97 & 87 & 33 & 59 & 57 \\
\hline $2016 / 2017$ & 141 & 84 & 85 & 86 & 91 & 54 & 60 & 61 \\
\hline $2017 / 2018$ & 120 & 69 & 83 & 85 & 76 & 38 & 61 & 52 \\
\hline $2018 / 2019$ & 117 & 76 & 55 & 70 & 73 & 44 & 62 & 29 \\
\hline $2019 / 2020$ & 89 & 47 & 58 & 67 & 58 & 18 & 67 & 39 \\
\hline \multicolumn{9}{|c|}{ Maksymalne średniodobowe stężenie pylów PM10 w sezonie grzewczym $\left[\mu \mathrm{g} / \mathrm{m}^{3}\right]$} \\
\hline $2012 / 2013$ & 402 & 335 & 269 & 265 & 300 & 226 & 191 & 244 \\
\hline $2013 / 2014$ & 256 & 214 & 190 & 180 & 177 & 128 & 114 & 221 \\
\hline $2014 / 2015$ & 206 & 191 & 171 & 184 & 153 & 116 & 109 & 169 \\
\hline $2015 / 2016$ & 329 & 294 & 299 & 206 & 293 & 124 & 163 & 201 \\
\hline $2016 / 2017$ & 327 & 338 & 303 & 196 & 314 & 195 & 218 & 150 \\
\hline $2017 / 2018$ & 224 & 192 & 187 & 157 & 186 & 123 & 119 & 135 \\
\hline $2018 / 2019$ & 165 & 184 & 107 & 176 & 172 & 143 & 114 & 113 \\
\hline $2019 / 2020$ & 143 & 116 & 107 & 128 & 155 & 101 & 76 & 160 \\
\hline \multicolumn{9}{|c|}{ Średnie średniodobowe stężenie pylów PM10 w sezonie grzewczym $\left[\mu \mathrm{g} / \mathrm{m}^{3}\right]$} \\
\hline $2012 / 2013$ & 93 & 68 & 68 & 65 & 69 & 45 & 47 & 54 \\
\hline $2013 / 2014$ & 75 & 60 & 59 & 54 & 54 & 38 & 38 & 48 \\
\hline $2014 / 2015$ & 83 & 56 & 61 & 56 & 55 & 39 & 42 & 44 \\
\hline $2015 / 2016$ & 78 & 56 & 58 & 58 & 54 & 35 & 43 & 42 \\
\hline $2016 / 2017$ & 79 & 63 & 57 & 60 & 64 & 41 & 50 & 43 \\
\hline $2017 / 2018$ & 62 & 49 & 51 & 51 & 50 & 35 & 39 & 40 \\
\hline $2018 / 2019$ & 61 & 47 & 39 & 48 & 45 & 37 & 37 & 30 \\
\hline $2019 / 2020$ & 52 & 37 & 37 & 43 & 43 & 25 & 30 & 33 \\
\hline
\end{tabular}

limitu zawartości pyłów PM10 w powietrzu przypada na sezony grzewcze od 2012/2013 do 2014/2015, po nich w większości przypadków następuje spadek liczby dni z przekroczeniami. Wyjątek stanowią dane ze stacji pomiarowej Trzebinia, dla której liczba dni z przekroczeniem dopuszczalnej zawartości pyłów PM10 w poszczególnych sezonach grzewczych utrzymuje się na w miarę jednakowym poziomie.

Należy również zwrócić uwagę na fakt, że maksymalne średniodobowe zawartości pyłów PM10 w powietrzu przekraczały wartość dopuszczalną dla aglomeracji krakowskiej nawet ośmiokrotnie (stacja Kraków, al. Krasińskiego, sezon 2012/2013), natomiast dla pozostałych stacji ponad sześciokrotnie (stacja Skawina, sezon 2016/2017) (rys. 3).

Analizując zmiany jakości powietrza w Małopolsce na przestrzeni lat 2012-2020, można zauważyć, że w ostatnich trzech sezonach grzewczych $(2017 / 2018,2018 / 2019$ oraz 2019/2020) w aglomeracji krakowskiej znacząco spadła zarówno maksymalna, jak i średnia zawartość pyłów PM10 mierzona w powietrzu. Jest to spowodowane najprawdopodobniej likwidacją dużej liczby kotłów na paliwa stałe, która nastąpiła na tym terenie w roku 2017. W nieco mniejszym stopniu tendencja ta jest zauważalna również w przypadku pozostałych analizowanych stacji zlokalizowanych w Małopolsce.

Drugim z zanieczyszczeń powietrza przyczyniającym się do powstawania smogu, dla którego dopuszczalną zawartość w powietrzu określono dla stężenia średniodobowego, jest ditlenek siarki. Dopuszczalna średniodobowa zawartość ditlenku siarki została określona na poziomie $125 \mu \mathrm{g} / \mathrm{m}^{3}$, a wartość ta może być przekroczona maksymalnie trzy razy w ciągu roku (GIOŚ, 2020). Zebrane przez Wojewódzki Inspektorat Ochrony Środowiska dane dotyczące jakości powietrza w zakresie zawartości ditlenku siarki wskazują, że jej dopuszczalne 


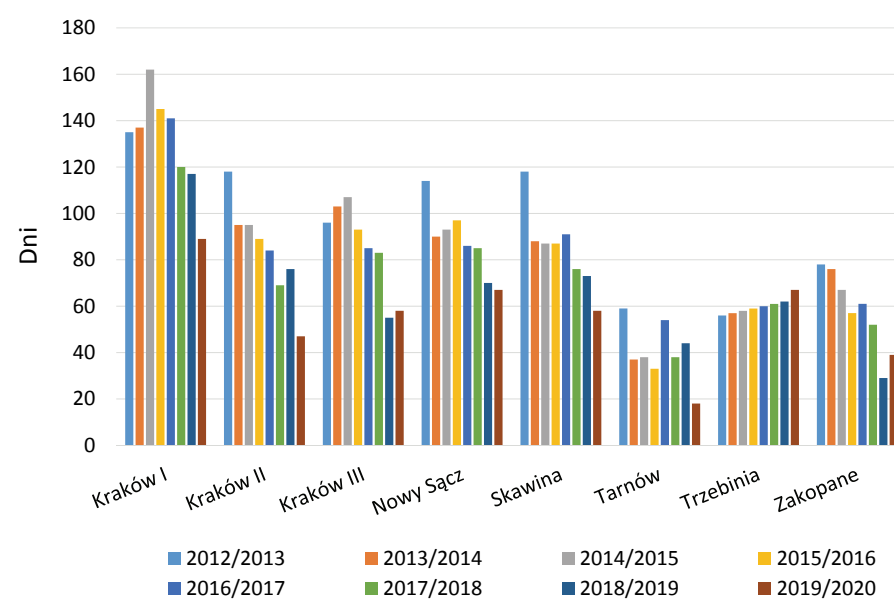

Rys. 2. Liczba dni z przekroczeniem wartości dopuszczalnej dla pyłów PM10 na poszczególnych stacjach pomiarowych (WIOŚ, 2020)

Fig. 2. Number of days in excess of the limit values for PM10 dust at individual measuring stations (WIOŚ, 2020)

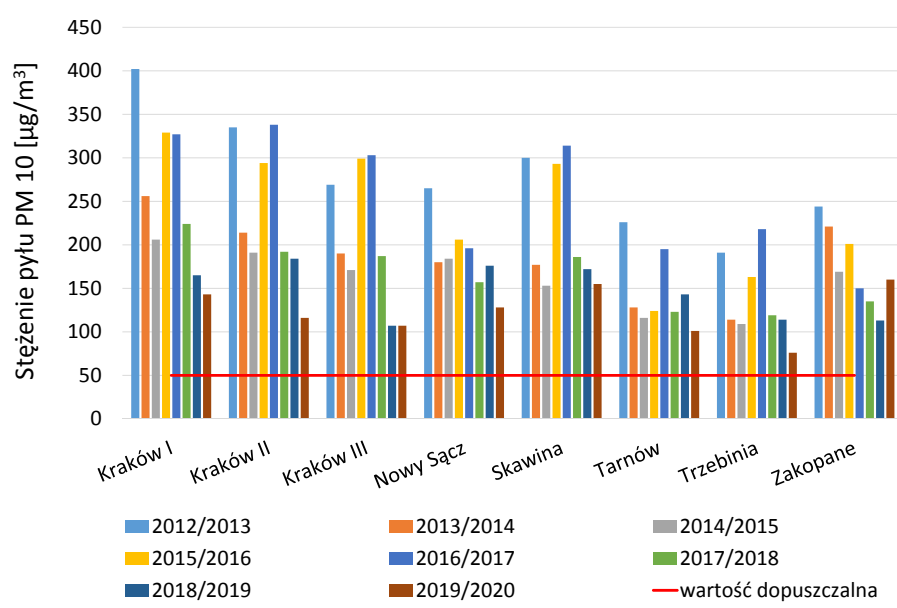

Rys. 3. Najwyższe średniodobowe wartości stężeń odnotowane dla pyłów PM10 na poszczególnych stacjach pomiarowych (WIOŚ, 2020)

Fig. 3. The highest daily average concentration of PM10 dust recorded at individual measuring stations (WIOŚ, 2020)

stężenie w powietrzu rzadko ulega przekroczeniu. W analizowanym okresie do przekroczenia tego parametru doszło tylko raz - w sezonie 2012/2013 przekroczenie zostało odnotowane na stacji zlokalizowanej w Trzebini. Na pozostałych stacjach pomiarowych maksymalne odnotowane średniodobowe stężenia ditlenku siarki nie przekraczały $72 \mu \mathrm{g} / \mathrm{m}^{3}$ (rys. 4), natomiast średnie średniodobowe zawartości ditlenku siarki nie przekraczały $25 \mu \mathrm{g} / \mathrm{m}^{3}$ (rys. 5).

Mimo że jakość powietrza w Małopolsce oceniana pod kątem występujących zanieczyszczeń ditlenkiem siarki jest bardzo dobra, to i tak zauważyć można, że uległa znaczącej poprawie na przestrzeni ostatnich trzech sezonów grzewczych. Jest to szczególnie wyraźne w przypadku analizy maksymalnych średniodobowych stężeń ditlenku siarki odnotowywanych w poszczególnych sezonach grzewczych. Wyjątek w tym zakresie stanowią dane uzyskane dla stacji Trzebinia oraz Tarnów. W przypadku stacji Trzebinia średnie średniodobowe stężenia ditlenku siarki uzyskane w sezonach grzewczych 2012/2013 oraz 2016/2017 są znacznie wyższe od wartości z pozostałych sezonów. Natomiast dla stacji Tarnów w całym analizowanym okresie zmiany zachodzące pomiędzy poszczególnymi sezonami grzewczymi są niewielkie.

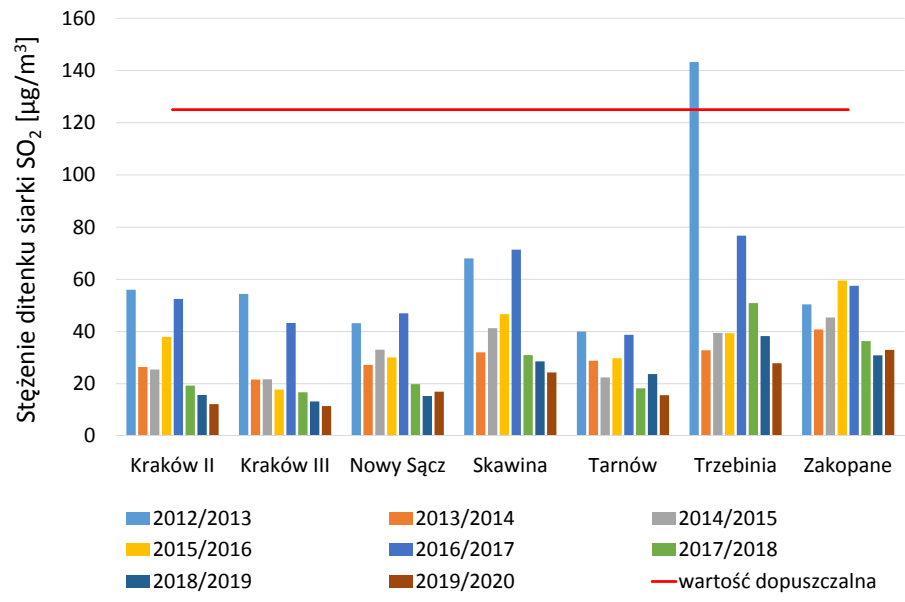

Rys. 4. Najwyższe średniodobowe wartości stężeń odnotowane dla ditlenku siarki na poszczególnych stacjach pomiarowych (WIOŚ, 2020)

Fig. 4. The highest daily average concentration of sulfur dioxide recorded at individual measuring stations (WIOŚ, 2020)

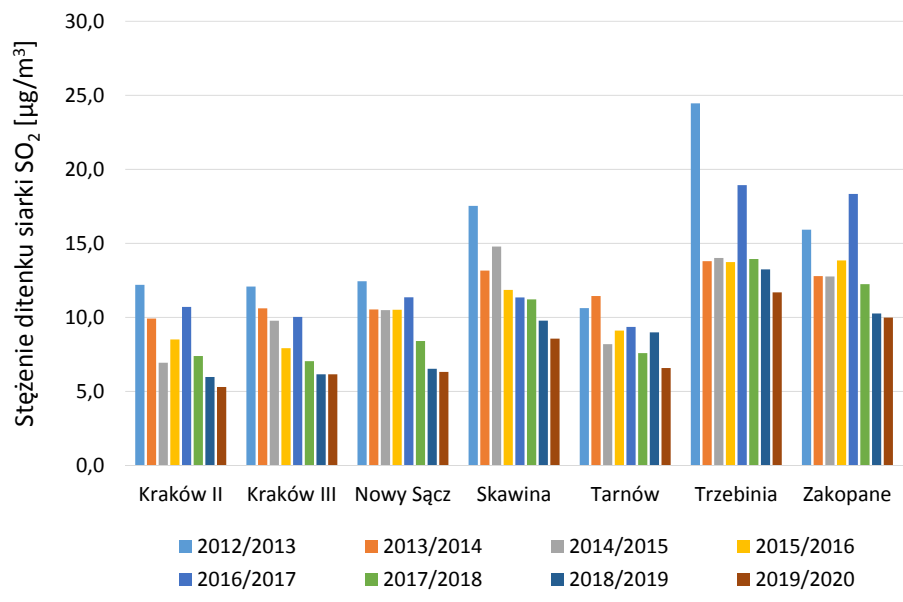

Rys. 5. Średnie średniodobowe wartości stężeń odnotowane dla ditlenku siarki na poszczególnych stacjach pomiarowych (WIOŚ, 2020)

Fig. 5. The average daily average concentration of sulfur dioxide recorded at individual measuring stations (WIOŚ, 2020)

Dwa zanieczyszczenia wchodzące w skład smogu, dla których określono wartości dopuszczalne stężeń średniorocznych, to (GIOŚ, 2020):

- zawartość pyłów PM2,5 - ich wartość dopuszczalna wynosi $25 \mu \mathrm{g} / \mathrm{m}^{3}$; 
- zawartość tlenków azotu - ich wartość dopuszczalna wynosi $30 \mu \mathrm{g} / \mathrm{m}^{3}$, wartość określona ze względu na ochronę roślin (ze względu na ochronę zdrowia ludzi określona została zawartość ditlenku azotu na poziomie $40 \mu \mathrm{g} / \mathrm{m}^{3}$, jednak ze względu na brak danych pomiarowych (WIOŚ, 2020) dla tego parametru analizie poddano sumaryczną zawartość tlenków azotu).

Dla rozpatrywanego okresu dane dotyczące zawartości pyłów PM2,5 w powietrzu dostępne są za lata 2014-2019 dla trzech stacji zlokalizowanych w aglomeracji krakowskiej (rys. 6).

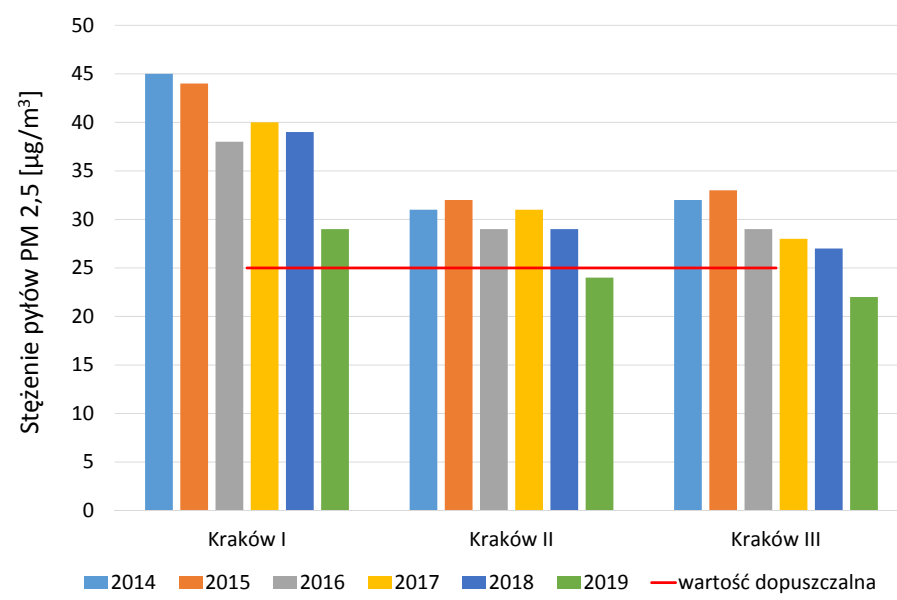

Rys. 6. Średnioroczna zawartość pyłów PM2,5 w powietrzu dla aglomeracji krakowskiej (WIOŚ, 2020)

Fig. 6. The average annual content of PM2.5 dust in the air for the Krakow agglomeration (WIOŚ, 2020)

Z danych przedstawionych na rysunku 6 wynika, że średnioroczna zawartość pyłów PM2,5 w Krakowie była przekroczona we wszystkich analizowanych lokalizacjach w latach 2014-2018. Dopiero w roku 2019 zanotowano brak przekroczeń dla stacji Kraków II oraz III, czyli Kurdwanowa i Nowej Huty. W przypadku wszystkich trzech stacji średnia zawartość pyłów PM2,5 odnotowana w 2019 roku była o około $20 \%$ niższa niż zawartość tych pyłów w roku 2018. Największy spadek zawartości pyłów PM2,5 na przestrzeni lat 2014-2019, wynoszący 35,5\%, odnotowano dla stacji Kraków I (al. Krasińskiego).

W zakresie zawartości tlenków azotu Wojewódzki Inspektorat Ochrony Środowiska udostępnia dane za lata 2014-2019 dla wszystkich wytypowanych do analizy stacji pomiarowych. $Z$ danych tych wynika, że zawartość tlenków azotu w aglomeracji krakowskiej znacznie przewyższa zawartości tego zanieczyszczenia odnotowywane w innych rejonach województwa (rys. 7 i 8).

Zawartość tlenków azotu w powietrzu, zarówno w przypadku aglomeracji krakowskiej, jak i pozostałych stacji zlokalizowanych w Małopolsce, przekracza wartość dopuszczalną, wynoszącą $30 \mu \mathrm{g} / \mathrm{m}^{3}$. Jedynie na stacji pomiarowej zlokalizowanej

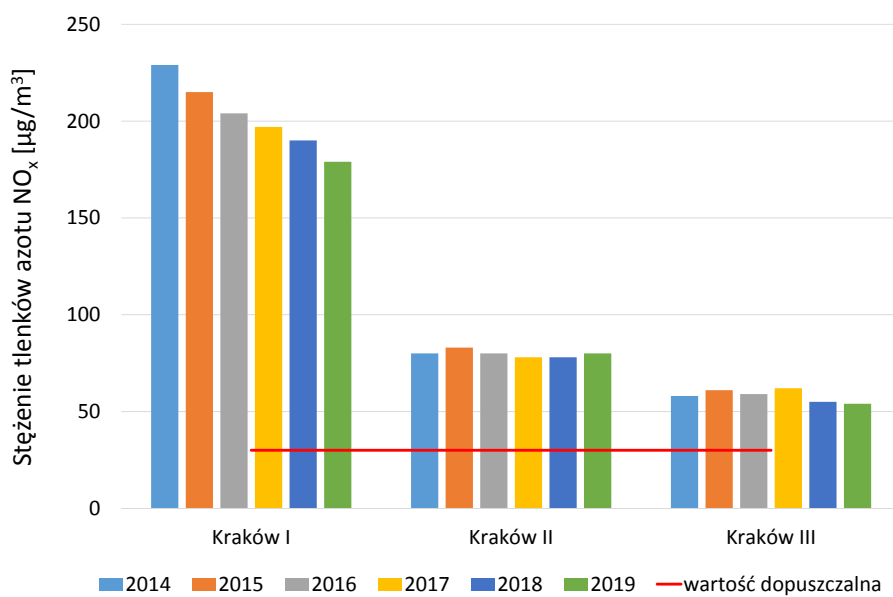

Rys. 7. Średnioroczna zawartość tlenków azotu w powietrzu dla aglomeracji krakowskiej (WIOŚ, 2020)

Fig. 7. Average annual content of nitrogen oxides in the air for the Krakow agglomeration (WIOŚ, 2020)

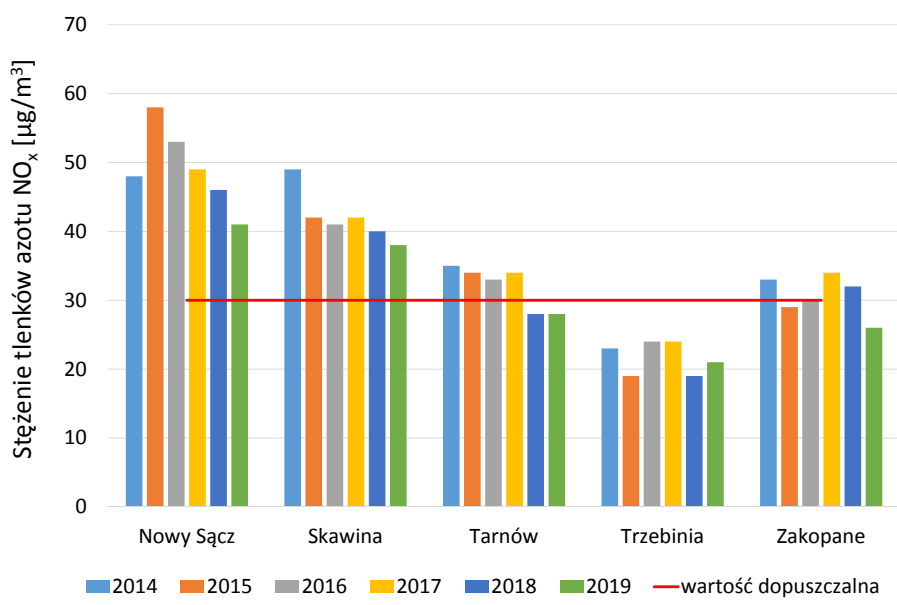

Rys. 8. Średnioroczna zawartość tlenków azotu w powietrzu dla pozostałych stacji pomiarowych Małopolski (WIOŚ, 2020)

Fig. 8. Average annual content of nitrogen oxides in the air for other measuring stations in Małopolska (WIOŚ, 2020)

w Trzebini wartość ta w latach 2014-2019 nie została ani razu przekroczona. Analizując dane dotyczące zawartości tlenków azotu w powietrzu dla aglomeracji krakowskiej, zauważyć można, że w przypadku stacji Kraków II oraz III odnotowywane w latach 2014-2019 średnioroczne zawartości tlenków azotu utrzymują się na w miarę zbliżonym poziomie, wynoszącym odpowiednio $80 \mu \mathrm{g} / \mathrm{m}^{3}$ oraz $60 \mu \mathrm{g} / \mathrm{m}^{3}$. Jeśli chodzi o stację Kraków I, to zauważalna jest tendencja spadkowa w odnotowywanych średniorocznych zawartościach tlenków azotu w powietrzu, jednak stężenia tlenków azotu rejestrowane na tej stacji są ponad dwukrotnie wyższe niż w przypadku pozostałych dwóch stacji krakowskich. Średnioroczna zawartość tlenków azotu w powietrzu mierzona poza aglomeracją krakowską jest znacznie niższa i jedynie na stacjach zlokalizowanych w Nowym Sączu i Skawinie rokrocznie dochodziło do przekroczeń wartości dopuszczalnych. Dodatkowo z wyników 
pomiarów na stacjach zlokalizowanych poza Krakowem wynika niewielka tendencja spadkowa w mierzonych wartościach średniorocznych stężeń tlenków azotu w powietrzu. Wyjątek stanowią stacje znajdujące się w Trzebini i Zakopanem, przy czym należy zauważyć, że w przypadku stacji w Trzebini w latach 2014-2019 nie dochodziło do przekroczeń dopuszczalnej średniorocznej zawartości tlenków azotu w powietrzu. Znacznie wyższe średnioroczne zawartości tlenków azotu występujące w aglomeracji krakowskiej niż poza nią oraz nawet siedmiokrotne przekroczenia wartości dopuszczalnej dla stacji zlokalizowanej w obrębie ważnej arterii komunikacyjnej Krakowa, jaką jest aleja Krasińskiego, wskazywać może, że głównym źródłem zanieczyszczenia tlenkami azotu jest transport samochodowy, nie zaś sektor komunalno-bytowy. Istotny wpływ transportu na zawartość tlenków azotu w powietrzu potwierdzają również dane literaturowe, z których wynika, że transport samochodowy odpowiada za około 63-70\% emisji tlenków azotu na terenach zurbanizowanych (Grzywa i Gliniak, 2014; Łepkowski et al., 2016).

Zanieczyszczeniem powietrza pochodzącym ze spalania paliw, które wchodzi w skład smogu, jest też tlenek węgla(II). Dla tego zanieczyszczenia określono stężenie dopuszczalne w odniesieniu do 8-godzinnego okresu uśredniania wyników. Uzyskana w ten sposób wartość wynosi $10000 \mu \mathrm{g} / \mathrm{m}^{3}$. $\mathrm{W}$ analizowanym okresie dane dla tego zanieczyszczenia dostępne były dla czterech stacji pomiarowych (Kraków I, Kraków III oraz Trzebinia i Zakopane) za lata od 2014 do 2020. W okresie tym nie odnotowano ani jednego przekroczenia wartości dopuszczalnej ustanowionej dla tego zanieczyszczenia. Porównując średnioroczne zawartości tlenku węgla(II) w powietrzu w poszczególnych latach, można zauważyć, że najwyższe zawartości odnotowywano na stacji Kraków I (rys. 9).

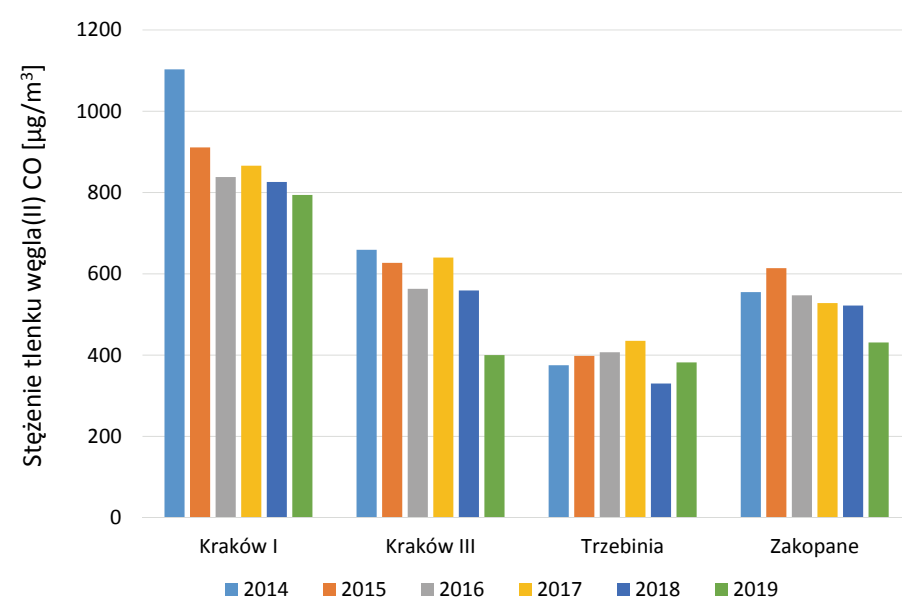

Rys. 9. Średnioroczna zawartość tlenku węgla(II) w powietrzu w Małopolsce (WIOŚ, 2020)

Fig. 9. The average annual content of carbon monoxide (II) in the air for Małopolska (WIOŚ, 2020)
Na stacjach pomiarowych zlokalizowanych w Krakowie i Zakopanem widać wyraźny spadek zawartości tlenku węgla(II) w powietrzu w latach 2014-2019, wynoszący od 22,3\% w Zakopanem do 39,3\% na stacji Kraków III (Nowa Huta). Inaczej wygląda sytuacja w przypadku stacji pomiarowej zlokalizowanej w Trzebini, gdzie najniższe średnioroczne stężenie tlenku węgla(II) odnotowano w 2018 roku, a w pozostałych latach średnioroczne stężenie tlenku węgla(II) utrzymywało się na zbliżonym poziomie, wynoszącym około $300 \mu \mathrm{g} / \mathrm{m}^{3}$.

\section{Podsumowanie i wnioski}

Analiza dostępnych danych pomiarowych za lata 20122020 dla stacji pomiarowych zlokalizowanych na terenie Małopolski wyraźnie pokazuje, że występują zanieczyszczenia, których dopuszczalna zawartość w powietrzu jest wielokrotnie przekraczana w ciągu roku na terenie całego województwa, a część przekroczeń stanowi wielokrotność wartości dopuszczalnej. Taka sytuacja wpływa negatywnie na zdrowie ludzi i roślinność. Zanieczyszczeniami, w przypadku których najczęściej dochodzi do przekroczeń wartości dopuszczalnych, są pyły zawieszone PM10 oraz PM2,5, a także tlenki azotu. Średnioroczna zawartość tlenków azotu była przekroczona w całym analizowanym okresie na pięciu stacjach pomiarowych, w tym wszystkich stacji zlokalizowanych w obrębie aglomeracji krakowskiej. Znacząco wyższe zawartości tlenków azotu rejestrowane na stacjach zlokalizowanych obok istotnych szlaków komunikacyjnych, gdzie odnotowywano nawet siedmiokrotne przekroczenia wartości dopuszczalnych, potwierdzają dostępne w literaturze dane dotyczące tego, że głównym źródłem emisji tlenków azotu do atmosfery jest transport samochodowy (Grzywa i Gliniak, 2014; Łepkowski et al., 2016). Istotny wpływ transportu na zawartość tlenków azotu w powietrzu powoduje, że działania podejmowane w ramach uchwał antysmogowych nie przynoszą zadowalających efektów, gdyż koncentrują się na ograniczaniu emisji zanieczyszczeń z sektora komunalnego, nie zaś z transportu (podejmowane w tym zakresie uchwały mają obecnie charakter pilotażowy). Natomiast w przypadku pyłów zawieszonych można zauważyć, że w ostatnich trzech sezonach grzewczych (2017/2018, 2018/2019 oraz 2019/2020) w aglomeracji krakowskiej znacząco spadła zarówno maksymalna, jak i średnia zawartość pyłów PM10 mierzonych w powietrzu, natomiast dla pyłów PM2,5 istotny spadek średniorocznego stężenia nastąpił w 2019 roku. Jest to najprawdopodobniej spowodowane likwidacją dużej liczby kotłów na paliwa stałe, jaka nastąpiła w Krakowie w latach 2017-2018. Utrzymujące się w Krakowie na zbliżonym poziomie maksymalna i średnia średniodobowa zawartość pyłów PM10 
w sezonach grzewczych 2018/2019 oraz 2019/2020 mogą świadczyć o tym, że maksymalny efekt ekologiczny miasto Kraków uzyskało poprzez wymianę pieców zasilanych paliwami stałymi, która nastąpiła przed rozpoczęciem sezonu grzewczego 2018/2019, natomiast dalsze ograniczenia związane $\mathrm{z}$ całkowitą eliminacją paliw stałych na tym terenie nie przyniosą już spektakularnych efektów. Nie można jednak na tej podstawie twierdzić, że obowiązujący zakaz stosowania paliw stałych nie przyczynił się do poprawy jakości powietrza, gdyż przyjęte w 2016 roku zapisy uchwały antysmogowej (Uchwała nr XVIII/243/16) mogły być dla wielu właścicieli urządzeń grzewczych na paliwa stałe zachętą do ich wcześniejszej likwidacji i wymiany na inne źródła ogrzewania. Dodatkowo należy zauważyć, że aglomeracja krakowska położona jest w kotlinie, dlatego też za jakość powietrza na jej terenie może również odpowiadać napływ zanieczyszczeń z innych gmin. Patrząc na postanowienia uchwały antysmogowej dla Małopolski (Uchwała nr XXXII/452/17), należy zauważyć, że jej zapisy wejda w pełni w życie dopiero w 2026 roku, a więc jej efekt ekologiczny będzie rozciągnięty w czasie. Bez wątpienia likwidacja około 12000 kotłów na paliwa stałe, do której doszło na terenie Małopolski w 2018 roku, przełoży się na poprawę jakości powietrza. Efekt ten może być jednak mniej widoczny w analizowanych danych pomiarowych ze względu na fakt, że brak jest możliwości skorelowania liczby zlikwidowanych kotłów w danej gminie $\mathrm{z}$ danymi pomiarowymi dla tej gminy. Mimo że na terenie Małopolski nadal występują istotne przekroczenia jakości norm powietrza, należy zauważyć, że podejmowane w tym województwie działania w zakresie poprawy jakości powietrza przynoszą powoli efekty. Jednak ich utrwalenie wymaga, aby działania takie podejmowane były z równą siłą we wszystkich gminach Małopolski.

\section{Literatura}

GIOŚ, Główny Inspektorat Ochrony Środowiska, 2020. Poziomy dopuszczalne zanieczyszczeń w powietrzu ze względu na ochronę zdrowia ludzi i ochronę roślin, terminy ich osiągnięcia oraz okresy, dla których uśrednia się wyniki pomiarów. <https://powietrze.gios.gov.pl/pjp/content/annual_assessment_air_acceptable level> (dostęp: 16.03.2020).

Głuszek J., Kosicka T.M., 2019. Wpływ smogu (zanieczyszczonego powietrza) na choroby układu sercowo-naczyniowego. Choroby Serca i Naczyń, 16(3): 201-206. DOI: 10.5603/ChSiN.2019.0030.

Grzywa A., Gliniak M., 2014. Wpływ rozwoju norm emisji spalin EURO na emisję zanieczyszczeń powietrza z pojazdów komunikacji miejskiej na przykładzie miasta Krakowa. Logistyka, 4: 4310-4314.

Holewa J., Kukulska-Zając E., Pęgielska M., 2012. Analiza możliwości wprowadzania biogazu do sieci przesyłowej. Nafta-Gaz, 8: 523-529.

Jaworski J., Kukulska-Zając E., Kułaga P., 2019. Wybrane zagadnienia dotyczące wpływu dodatku wodoru do gazu ziemnego na elementy systemu gazowniczego. Nafta-Gaz, 10: 625-632. DOI: 10.18668/NG.2019.10.04

Jaworski J., Kułaga P., Blacharski T., 2020. Study of the Effect of Addition of Hydrogen to Natural Gas on Diaphragm Gas Meters. Energies, 13(11): 3006. DOI: 10.3390/en13113006.

Kamiński A., 2019. Odpowiedzialność za smog. Przemyst Chemiczny, 6: 847-851. DOI: 10.15199/62.2019.6.2.

Kołodziejak G., 2012. Możliwości wykorzystania potencjału energetycznego biogazu powstającego w trakcie procesu oczyszczania ścieków. Analiza opłacalności proponowanych rozwiązań. Nafta-Gaz, 12: 1036-1046.

Kuchcik M., Milewski P., 2018. Zanieczyszczenie powietrza w Polsce - stan, przyczyny i skutki. Czasopismo Polskiej Akademii Nauk. <https://journals.pan.pl/Content/107643/PDF/ Studia+KPZK+182+t.II+13+Kuchcik\%2C+Milewski.pdf $>$ (dostęp: 31.07.2020).

Life-Mappingair/PL, 2019. Uchwały antysmogowe w Polsce. <https:// mappingair.meteo.uni.wroc.pl/2019/09/uchwaly-antysmogowew-polsce/> (dostęp: 15.03.2020).

Łepkowski M., Walendzik M., Nowacki G., 2016. Wpływ transportu drogowego na środowisko naturalne człowieka i zagrożenia występujące w transporcie drogowym rzeczy. Autobusy: Technika, Eksploatacja, Systemy Transportowe, 6: 459-464.

PKEE, 2018, Energetyka kocha czyste powietrze. $<$ https://www pkee.pl/energetyka-kocha-czyste-powietrze-raport-pkee/> (dostęp:31.07.2020).

Podsumowanie realizacji Programu ochrony powietrza dla województwa małopolskiego za 2013 rok. <https://powietrze.malopolska.pl/wp-content/plugins/download-attachments/includes/ download.php?id=14699> (dostęp: 31.07 .2020$)$.

Podsumowanie realizacji Programu ochrony powietrza dla województwa małopolskiego za 2014 rok. <https://powietrze.malopolska.pl/wp-content/plugins/download-attachments/includes/ download.php?id=14698> (dostęp: 31.07 .2020$)$

Podsumowanie realizacji Programu ochrony powietrza dla województwa małopolskiego za 2015 rok. <https://powietrze.malopolska.pl/wp-content/plugins/download-attachments/includes/ download.php?id=14697> (dostęp: 31.07.2020).

Podsumowanie realizacji Programu ochrony powietrza dla województwa małopolskiego za 2016 rok. <https://powietrze.malopolska.pl/wp-content/plugins/download-attachments/includes/ download.php?id=20694> (dostęp: 31.07 .2020$)$.

Podsumowanie realizacji Programu ochrony powietrza dla województwa małopolskiego za 2017 rok. <https://powietrze.malopolska.pl/wp-content/plugins/download-attachments/includes/ download.php?id=19524> (dostęp: 31.07 .2020$)$.

Podsumowanie realizacji Programu ochrony powietrza dla województwa małopolskiego za 2018 rok. <https://powietrze.malopolska.pl/wp-content/plugins/download-attachments/includes/ download.php?id=32705> (dostęp: 31.07 .2020$)$.

Polski Alarm Smogowy, 2019. Uchwały antysmogowe. $<$ https://polskialarmsmogowy.pl/polski-alarm-smogowy/jakwygrac/szczegoly,uchwaly-antysmogowe, 27.html> (dostęp: 15.03.2020).

Rogowska D., 2014. Przegląd dobrowolnych systemów certyfikacji biopaliw na zgodność z kryteriami zrównoważonego rozwoju. Nafta-Gaz, 4: 256-261.

Rogowska D., 2015. The system of biofuels sustainability in Poland. Nafta-Gaz, 7: 487-493.

Rogowska D., 2017. Ocena wpływu czynników występujących na etapie uprawy na emisję GHG w cyklu życia bioetanolu. NaftaGaz, 2: 119-125. DOI: 10.18668/NG.2017.02.07. 
Rogowska D., 2018. Produkcja biopaliw jako element gospodarki o obiegu zamkniętym. Nafta-Gaz, 2: 156-163. DOI: 10.18668/ NG.2018.02.10.

Rogowska D., Berdechowski K., Laczek T., 2016. The development of the KZR INiG System - european certification scheme. NaftaGaz, 5: 370-375. DOI: 10.18668/NG.2016.05.09.

Schuster T., Holewa-Rataj J., Kukulska-Zając E., 2019. Ocena jakości paliw gazowych w kontekście wprowadzania wodoru do sieci gazu ziemnego. Gaz, Woda i Technika Sanitarna, 2: 42-46.

Siuda T., Wojtowicz R., 2016. Badania możliwości współspalania biogazu rolniczego i LNG lub LPG w urządzeniach użytku domowego oraz w urządzeniach do zastosowań przemysłowych. Nafta-Gaz, 9: 747-754. DOI: 10.18668/NG.2016.09.10.

Stala-Szlugaj K., 2018. Uchwały antysmogowe w Polsce a ich oddziaływanie na zużycie węgla kamiennego w gospodarstwach domowych. Journal of the Polish Mineral Engineering Society, 2: 161-168. DOI: 10.29227/IM-2018-02-21.

Treder M., 2017. Smog zagrożeniem bezpieczeństwa zdrowotnego w Polsce. Rocznik Bezpieczeństwa Międzynarodowego, 11(1), 190-204.

Urząd Marszałkowski Województwa Małopolskiego, Departament Środowiska, 2020a. Efekty realizacji programu ochrony powietrza. $<$ https://powietrze.malopolska.pl/program-ochrony-powietrza/ efekty-realizacji/> (dostęp: 15.03.2020).

Urząd Marszałkowski Województwa Małopolskiego, Departament Środowiska, 2020b. Uchwała antysmogowa dla Krakowa. $<$ https://powietrze.malopolska.pl/antysmogowa/krakow/> (dostęp: 15.03.2020).

Urzad Marszałkowski Województwa Małopolskiego, Departament Środowiska, 2020c. Uchwała antysmogowa dla Małopolski $<$ https://powietrze.malopolska.pl/antysmogowa/malopolska/> (dostęp: 15.03.2020).

WIOŚ, Wojewódzki Inspektorat Ochrony Środowiska w Krakowie, 2020. Prezentacja pomiarów. <http://monitoring.krakow.pios. gov.pl/dane-pomiarowe> (dostęp: marzec 2020).

Wojtowicz R., 2019. An analysis of the effects of hydrogen addition to natural gas on the work of gas appliances. Nafta-Gaz, 8: 465-472. DOI: 10.18668/NG.2019.08.03.

\section{Akty prawne i normatywne}

PN-EN 303-5:2012 Kotły grzewcze - Część 5: Kotły grzewcze na paliwa stałe z ręcznym i automatycznym zasypem paliwa o mocy nominalnej do $500 \mathrm{~kW}$ - Terminologia, wymagania, badania i oznakowanie.

Rozporządzenie Komisji (UE) 2015/1189 z dnia 28 kwietnia 2015 r. w sprawie wykonania dyrektywy Parlamentu Europejskiego i Rady 2009/125/WE w odniesieniu do wymogów dotyczących ekoprojektu dla kotłów na paliwo stałe.

Uchwała Nr XVIII/243/16 Sejmiku Województwa Małopolskiego z dnia 15 stycznia 2016 r. w sprawie wprowadzenia na obszarze Gminy Miejskiej Kraków ograniczeń w zakresie eksploatacji instalacji, w których następuje spalanie paliw.

Uchwała Nr XXXII/452/17 Sejmiku Województwa Małopolskiego z dnia 23 stycznia $2017 \mathrm{r}$. w sprawie wprowadzenia na obszarze województwa małopolskiego ograniczeń i zakazów w zakresie eksploatacji instalacji, w których następuje spalanie paliw.

Ustawa z dnia 10 września 2015 r. o zmianie ustawy - Prawo ochrony środowiska (Dz.U. z 2015 r. poz. 1593).

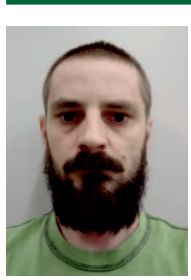

Mgr inż. Mateusz RATAJ

Asystent w Zakładzie Użytkowania Paliw

Instytut Nafty i Gazu - Państwowy Instytut Badawczy

ul. Lubicz 25 A

31-503 Kraków

E-mail: mateusz.rataj@inig.pl

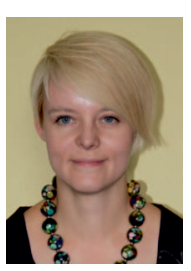

Mgr Jadwiga HOLEWA-RATAJ

Starszy specjalista badawczo-techniczny w Zakładzie Ochrony Środowiska

Instytut Nafty i Gazu - Państwowy Instytut Badawczy ul. Lubicz 25 A

31-503 Kraków

E-mail: jadwiga.holewa@inig.pl 